\title{
Intermitten Irrigation on Rice Varieties in Watersheds
}

\author{
I G.K.Dana Arsana ${ }^{1}$, Made J.Mejaya ${ }^{2 *}$ \\ ${ }^{1}$ Bali Agricultural Technology Assessment Institute \\ ${ }^{2}$ Indonesian Legume and Tuber Crops Research Institute
}

*Corresponding Author: Made J.Mejaya, Indonesian Legume and Tuber Crops Research Institute

\begin{abstract}
The impact of stress water deficit on watersheds can reduce rice production to experience crop failure. Research on efficient use of water resources in rice plants in the watershed aims: 1). study the influence of the way intermittent irrigation on growth, yield and yield components of several paddy rice varieties in the location position in the watershed; and 2). look for ways of intermittent irrigation that were suitable for each variety at the location position in the watershed. The research was carried out simultaneously for the upstream, middle and downstream sub-watershed locations using the same design and treatment, namely Split Plot Design with 3 replications. The main plot was the irrigation technique $(P)$ conswasting of:P1 = Watering continues or continuous flow, ie water was inundated and continues to flow; $P 2=$ Intermittent irrigation or rotational irrigation which was stagnant water every 4 days; and $P 3=$ Irrigation intermittently ie water was flooded once every 8 days. The subplots were rice varieties $(V)$ conswasting of: $V 1=$ Mekongga rice variety; $V 2=$ Inpari 1 rice variety; and V3 = Inpari 10 Laeya rice variety. The results of the study showed that irrigation irregularly every 8 days resulted in the weight of milled unhulled rice terrains was high, while the lowest weight of dry milled rice was produced from continuous irrigation. The new superior rice varieties Inpari 10 Laeya produce the highest weight of dry milled rice. The location of the upstream watershed produces the highest dry milled grain weight, while the lowest in the middle watershed location.
\end{abstract}

Keywords: intermittent, irrigation, rice, variety, watershed.

\section{INTRODUCTION}

International rice experts argue that Green Revolution technology negatively impacts soil physicalchemical conditions and calls thwas phenomenon soil soil fatigue or soil sickness. There was a tendency for input efficiency to be lower. To achieve the same level of rice production, more inputs were needed, and the rate of increase in production tends to be sloping, even decreasing (Fagi et.al, 2009). The interaction of the contribution of water irrigation $x$ superior varieties $x$ fertilizing accounted for $75 \%$. So, even though irrigation water contributes the most, but it does not have a big impact if it was not planted with superior varieties, and superior varieties need high-dose fertilization. In total irrigated rice accounts for around 54\% of national rice production (FAO, 1996; Huke and Huke, 1998).

The research of international cooperation to overcome the condition concluded that soil fatigue or soil sickness does occur, but was not widespread and easily overcome(Fagi et al., 2002). The results of international collaboration research produced a technological package to overcome soil sickness and spurred the rate of increase in rice production, namely: 1) fertilizing organic matter;2) fertilizing $\mathrm{N}, \mathrm{P}$, $\mathrm{K}$ according to soil analyswas; 3 ) improving fertilizer adminwastration time $\mathrm{N}$ by using leaf color chart; and 4) drying rice fields regularly/rotating especially in the dry season where the volume of irrigation water was limited.

Lowland rice plants need enough water for their cultivation activities. According to UNESCO-IHEWaterfootprint in Subagyono and Sumarini (2007), to produce $1 \mathrm{~kg}$ of rice requires 2,300 liters of water, for $1 \mathrm{~kg}$ of 900 liters of corn, and for domestic needs of water every 100 liters of capita- 1 with an estimated dwascharge requirement for cultivation paddy 1 liter 1 second. The impact of water deficit stress can reduce the production of irrigated rice, rainfed lowland rice and upland rice. Engelman\& Le Roy (1993) define water stress and scarcity, which can be used to assess the potential status of water resources from regions in Indonesia. Wereas with water resources availability of 1000- 
$1600 \mathrm{~m} 3$ / capita / year will suffer from water stress, especially in dry years. Regions experience scarcity of water, if annual water resources were replaced by less than $1000 \mathrm{~m} 3$ / capita / year.

Under stress and scarcity of water face serious obstacles to water availability for socio-economic and environmental development. One way to overcome the limitations of water volume in rice plants was wet-dry irrigation which depends on the type of soil and the depth of the surface of the groundwater. Soil textured with shallow groundwater $(10-40 \mathrm{~cm})$, relatively little water loss compwered to sandy textured soil. Dry wet irrigation began to be applied since rice plants were 10 days after planting until two weeks before harvest, except for a week before and a week after flowering the fields were flooded with 3-5 cm of water. Thwas method does not reduce grain yield, even in certain conditions the grain yield actually increases (Bouman et.al, 2007). Ogunremi (1991) in Sharma et al. (1994) observed an increase in rice root length if the groundwater status changed from unsaturated to saturated. In flooded rice roots absorb most of the oxygen through aerenchym. Soil texture indicates soil pore size dwastribution (porosity) and affects the roots of rice plants (Karet. Al, 1979, in Sharma, 1994).

Based on observations in several watersheds itwas estimated that around $65.9 \%$ of rainwater was depleted into surface water (Pawitan et.al, 1996). Surface water was accommodated in rivers and forms cumulative water dwascharge, and some were stored in lakes and reservoirs. Lack of attention to watershed conservation and the neglect of local wwasdom in watershed management lead to degradation of forest, land and water resources (Noordwijk et.al, 2004). The watershed was generally defined as an expanse of werea / werea which was limited by topographic boundaries (the ridge that receives, collects rainwater, sediment and nutrients and flows it through tributaries and enters the main river eventually into the sea or into lakes or reservoirs). Thus all regions were divided into watershed units (Asdak, 1995). These watershed units were so numerous because $45 \%$ of Indonesia's land wereaconswasts of hills and mountains (Chiu et. Al. 2000).

In the past 20 years, the werea of paddy fields in Bali has decreased from 98,000 ha to 87,850 ha or $11.5 \%$ depreciation (Arsana, 2006), and rice productivity has decreased by $0.1 \%$ and production has decreased $0.2 \%$ per year (Arsana, 2006) . Factors related to soil conditions, estimated as a cause of declining rice productivity (Arsana et.al, 2003; Fagi et.al, 2002). One of the major rivers in Bali that flows water continuously was the Yeh Ho river in Tabanandwastrict. In the Yeh Ho watershed, 50\% of the rice paddy wereawas in the plain, while the rest was in the werea with a hilly topography of paddy fields on the terrace. The source of the water of the river Yeh Ho comes from springs and rain water which when in the dry season, water availability was limited. The impact of stress water deficit on the watershed was that it can reduce rice production until it experiences crop failure. Therefore research on efficient use of water resources in rice plants in the watershed aims: 1). Studying the effect of intermittent irrigation on growth, yield and yield components of several paddy rice varieties in three location positions in the watershed; and 2). Looking for intermittent irrigation methods that were suitable for each variety at the location position in the watershed.

\section{Materials AND Methods}

\subsection{Location and Time of Implementation}

The research was carried out on farmers' land in a series of experiments in the Subak region representing sub-watersheds upstream, middle and downstream of the Yeh Ho watershed. Experiments in the upstream sub-watershed were carried out in WangayaBetanSubak, Penebel District, Tabanan Regency, Bali Province. Place height \pm 564meters above sea level (m ASL). Experiments in the middle sub-watershed were placed in SubakMeliling, KerambitanDwastrict. At an altitude of $\pm 152 \mathrm{~m}$ ASL. Research in the downstream sub-watershed was located in SubakTibuBiyu, Kerambitan District at an altitude of $\pm 40 \mathrm{~m}$ ASL. One research unit was placed in each location during the 2010 planting season.

The research was carried out simultaneously for the upstream, middle and downstream sub-watershed locations using the same design and treatment, namely Split Plot Design with 3 replications. The main plot was the irrigation technique (I) conswasting of:

I1 = Continuous flow with stagnant and flowing water;

I2 = Irrigation intermittently with stagnant water every 4 days; and

I3 = Irrigation intermittently with stagnant water every 8 days.

The subplot was a rice variety $(\mathrm{V})$ consisting of: 
$\begin{aligned} \text { V1 } & =\text { Mekongga rice variety; } \\ \text { V2 } & =\text { Inpari } 1 \text { rice variety; and } \\ \text { V3 } & =\text { Inpari } 10 \text { Laeya rice variety. }\end{aligned}$

\subsection{Implementation}

Land preparation begins with processing and soil lubrication followed by rice planting time. When planting the soil conditions in a saturated state of the field. At the time of processing the former harvested rice field, it was cleaned to avoid the source of tungrodwasease. The size of the center of the embankment was planted plastic with a depth of $40 \mathrm{~cm}$ to avoid inter-plot water seepage. Seeds aged 15-21 were planted with 2-3 seeds per hole with a spacing of $25 \mathrm{~cm}$ x $25 \mathrm{~cm}$. Weed was controlled according to the condition of weed growth. Plant pest organwasmswere controlled by the principle of integrated pest control such as controlling rats using plastic fences and combinations with wire mesh.

In each plot a perforated tube was planted with a dwastance of 1 meter from the embankment, not close to an irrigation canal or drainage channel. Drawings of Appendix tube 15. Irrigation with an alternative method of wet-dry starts from 3 days after planting (DAP); map of water 2-3 cm; thwas puddle was valid for (5-10) until the depth of the groundwater in the paralon tube reaches $15 \mathrm{~cm}$ from the ground; then the plots were flooded $2-3 \mathrm{~cm}$ deep; thwas method was regulated according to treatment until 10 days before harvest. Weeding was done once because there were not many weeds that grow. Weed weeding was also done with porcupines, weeds that were not uprooted by weed porcupines pulled by hand, especially weeds that were too close to the main plants. rice fields during weeding with $2-3 \mathrm{~cm}$ porcupines for continuous irrigation treatment. While the plots that get irrigation every 8 days feel a bit heavy to run porcupines.

Harvesting was done after the rice wasyelloww according to the age of the plant, calculated from the time the seed spreads to harvest. The data of the tea was taken randomly in the middle of the plot with a size of $2 \mathrm{~m} \times 3 \mathrm{~m}$; the water content of dried grain harvested yields was measured by 3 replications of mowastur tester. The straw produced was weighed.

\subsubsection{Plant Observations Include:}

1. Plant height and number of tillers per clump were observed from 15 - 85 days after plantingwith 7 daily observation times. The harvest time was the same as the panicle count at harvest. In thwas observation five clumps of plants were measured randomly from the sample werea in the experimental plot.

2. The weight of dried roots and biomass when flowering: examples of plants were separated from the roots and top pieces. An example of a root was taken when the plant was $100 \%$ flowering (root formation reaches its maximum) of two clumps per plot of treatment with the "core method", namely by using a metal cylinder tube $30 \mathrm{~cm}$ long and $20 \mathrm{~cm}$ in diameter. The sample plant clumps to be used were taken randomly in the sample werea. After the root sample was cleaned, air was dried for a few days, then the root volume was determined by inserting the root sample into a measuring cup containing $500 \mathrm{ml}$ of water. Changing the water in a measuring cup was the root volume expressed in milliliters per clump. For example, the root and top pieces were air dried for several days and then heated at $70^{\circ} \mathrm{C}$ for $2 \times 24$ hours to determine the dry weight per root.

3. Component yield: the number of tillers per clump was determined by calculating the total number of productive tillers (tillers that produce panicles); number of panicles per clump: determined by calculating the number of panicles per clump; the number of grain per panicle (empty grain and filled grain) was calculated by the number of filled grain and empty grain, then calculated the average number of grain per panicle and percentage of filled grain; weight of 1000 seeds: determined from the result of weighing 1,000 grain contents at $14 \%$ mowasture content in grams. The yield component was calculated after the crop was harvested from 5 sample plant clumps per plot randomly.

4. Grain yield $=\mathrm{kg} / \mathrm{ha}$ grain weight (grain moisture content of $14 \%$ ), which was the weight of the grain weighed from the tile plots in each treatment with a size of 2 meters $\times 3$ meters in the middle of the plot. The grain yields from the plots were then measured (three times) by "grain mowasture tester". The grain yield was expressed in $\mathrm{kg} / \mathrm{ha}$ at $14 \%$ grain water content (dry unhulled rice paddy). 
Data from the observations were analyzed for variance to determine the significance of the effects of water treatment and varieties and interactions using the $\mathrm{F}$ test at the levels of $5 \%$ and $1 \%$. If there was a significant (significant) effect of the treatment for a particular character, then the comparwason of the average pair of characters was then tested based on Duncan's Multiple Dwastance with a level of $5 \%$ and $1 \%$. Combined analysis was to compwere data in each part of the sub-watershed. To find out the relationship between the results and the supporting factors the results were used regression analyswas with a stepwise.

\section{RESUlTS AND DWASCUSSION}

\subsection{Physical Components of Soils}

Overall soil $\mathrm{pH}$ in the upstream watershed location ( $\mathrm{pH} 4.28)$ appeared lower than the middle location $(\mathrm{pH}$ 5.17) and downstream $(\mathrm{pH}$ 5.83) and was significantly different (Table 1). The further downstream the higher $\mathrm{pH}$ was thought to be due to soil enrichment by irrigation water. At the location of the upstream watershed, each Mekongga, Inpari 1 and Inpari 10 varieties did not appear to be significantly different after being given continuous irrigation treatment, irrigation every 4 days and irrigation every 8 days. In the middle watershed location, soil $\mathrm{pH}$ was significantly different for Inpari 10 varieties after being given continuous irrigation, irrigation 4 days and once every 8 days with a pH value of 5.08; 5,21; and 5.59. Based on the data, the more the downstream werea, the higher the $\mathrm{pH}$ of the land compwered to the location of the watershed in the middle and the location of the watershed upstream. The further downstream the higher $\mathrm{pH}$ was thought to be due to soil enrichment by irrigation water.

Table1. Effect of watershedlocation, irrigation technique and varieties on soil $\mathrm{pH}$

\begin{tabular}{|c|c|c|c|c|c|}
\hline \multirow{3}{*}{$\begin{array}{c}\text { WatershedLocat } \\
\text { ion }\end{array}$} & \multirow{3}{*}{ Irrigation Technique } & \multicolumn{4}{|c|}{ Soil pH } \\
\hline & & \multicolumn{3}{|c|}{ Varieties } & \multirow{2}{*}{ Average } \\
\hline & & Mekongga & Inpari 1 & Inpari 10 Laeya & \\
\hline \multirow[t]{4}{*}{ Upstream } & Continuous & $4.14^{\mathrm{g}}$ & $4.30^{\mathrm{fg}}$ & $4.33^{\mathrm{fg}}$ & 4.26 \\
\hline & Every 4 days & $4.26^{\mathrm{g}}$ & $4.32^{\mathrm{fg}}$ & $4.32^{\mathrm{fg}}$ & 4.30 \\
\hline & Every 8 days & $4.21^{\mathrm{g}}$ & $4.30^{\mathrm{fg}}$ & $4.33^{\mathrm{fg}}$ & 4.28 \\
\hline & Average & 4.20 & 4.31 & 4.33 & 4.28 \\
\hline \multirow[t]{4}{*}{ Middle } & Continuous & $5.30^{\mathrm{b}-\mathrm{e}}$ & $5.17^{\mathrm{c}-\mathrm{e}}$ & $5.08^{\mathrm{de}}$ & 5.18 \\
\hline & Every 4 days & $4.96^{\mathrm{e}}$ & $5.31^{\mathrm{a}-\mathrm{e}}$ & $5.21^{\mathrm{c}-\mathrm{e}}$ & 5.16 \\
\hline & Every 8 days & $4.93^{e-f}$ & $4.95^{\mathrm{e}-\mathrm{f}}$ & $5.59^{\mathrm{a}-\mathrm{e}}$ & 5.16 \\
\hline & Average & 5.06 & 5.14 & 5.29 & 5.17 \\
\hline \multirow[t]{4}{*}{ Downstream } & Continuous & $5.67^{\mathrm{a}-\mathrm{d}}$ & $5.97^{\mathrm{a}-\mathrm{b}}$ & $6.08^{\mathrm{a}}$ & 5.91 \\
\hline & Every 4 days & $5.81^{\mathrm{acc}}$ & $5.68^{a-d}$ & $6.00^{\mathrm{ab}}$ & 5.83 \\
\hline & Every8 days & $5.74^{\mathrm{a}-\mathrm{d}}$ & $5.70^{\mathrm{a}-\mathrm{d}}$ & $5.78^{\mathrm{a}-\mathrm{c}}$ & 5.74 \\
\hline & Average & 5.74 & 5.78 & 5.95 & 5.83 \\
\hline
\end{tabular}

Note: Numbers in the same column and row followed by the same lettersignificantly different based on 5\% $D M R T$

Table 2 shows the concentration of soil C-Organic in the upstream watershed location on an average 8 days irrigation has higher $\mathrm{C}$-organic content of soil than irrigation 4 days and continuously with $\mathrm{C}$ Organic value of $2.23 \%$ respectively; $2.34 \%$; and $2.41 \%$. The middle werea between the irrigation treatment appears to be significantly different as well as the differences in the rice varieties used. In the downstream werea the treatment of irrigation and varieties also caused significant differences between treatments. Overall, the concentration of C-Organic soil was evenly dwastributed from upstream, middle and downstream. It was suspected that differences in rice yields were not caused by C-organic soil / soil fertility.

Table2. Effect of watershedlocation, irrigation technique, and varieties on soil C-organic concentration

\begin{tabular}{|c|c|c|c|c|c|}
\hline \multirow{3}{*}{$\begin{array}{c}\text { Watershed } \\
\text { Location }\end{array}$} & \multirow{2}{*}{$\begin{array}{c}\text { Irrigation } \\
\text { Technique }\end{array}$} & \multicolumn{4}{|c|}{ Concentration of soil C-Organic (\%) } \\
\cline { 3 - 5 } & & \multicolumn{3}{|c|}{ Varieties } & \multirow{2}{*}{ Average } \\
\cline { 3 - 5 } & Continuous & $2.24^{\mathrm{a}-\mathrm{d}}$ & $2.20^{\mathrm{b}-\mathrm{d}}$ & $2.25^{\mathrm{a}-\mathrm{d}}$ & 2.23 \\
\hline Upstream & Mekonga & Inpari 1 & $2.30^{\mathrm{a}-\mathrm{c}}$ & 2.34 \\
\hline & Every 4 days & $2.27^{\mathrm{a}-\mathrm{d}}$ & $2.47^{\mathrm{ab}}$ & $2.44^{\mathrm{a}-\mathrm{c}}$ & 2.41 \\
\hline & Every 8 days & $2.31^{\mathrm{a}-\mathrm{c}}$ & $2.49^{\mathrm{ab}}$ & $\mathbf{2 . 3 3}$ & $\mathbf{2 . 3 3}$ \\
\hline
\end{tabular}




\begin{tabular}{|c|c|c|c|c|c|}
\hline \multicolumn{7}{|c|}{} & \multicolumn{2}{c|}{} & $2.27^{\mathrm{a}-\mathrm{d}}$ & 2.33 \\
\hline Middle & Continuous & $2.20^{\mathrm{b}-\mathrm{d}}$ & $2.52^{\mathrm{a}}$ & $2.38^{\mathrm{a}-\mathrm{c}}$ & 2.34 \\
\hline & Every 4 days & $2.33^{\mathrm{a}-\mathrm{c}}$ & $2.32^{\mathrm{a}-\mathrm{c}}$ & $1.99^{\mathrm{d}}$ & 2.13 \\
\hline & Every 8 days & $2.27^{\mathrm{a}-\mathrm{d}}$ & $2.15^{\mathrm{cd}}$ & $\mathbf{2 . 2 1}$ & $\mathbf{2 . 2 7}$ \\
\hline & Average & $\mathbf{2 . 2 7}$ & $\mathbf{2 . 3 3}$ & $2.45^{\mathrm{a}-\mathrm{c}}$ & 2.47 \\
\hline & Continuous & $2.46^{\mathrm{ab}}$ & $2.52^{\mathrm{a}}$ & $2.38^{\mathrm{a}-\mathrm{c}}$ & 2.38 \\
\hline & Every 4 days & $2.31^{\mathrm{a}-\mathrm{c}}$ & $2.45^{\mathrm{a}-\mathrm{c}}$ & $2.37^{\mathrm{a}-\mathrm{c}}$ & 2.33 \\
\hline & Every8 days & $2.33^{\mathrm{a}-\mathrm{c}}$ & $2.31^{\mathrm{a}-\mathrm{c}}$ & $\mathbf{2 . 4 0}$ & $\mathbf{2 . 3 9}$ \\
\hline
\end{tabular}

Note: Numbers in the same column and row followed by the same lettersignificantly different based on 5\% DMRT

The concentration of C-Organic soil in the upstream werea irrigation was 8 days higher than irrigation 4 days and continuously. The middle werea between irrigation treatments was significantly different. In the downstream werea the treatment of irrigation and varieties also caused significant differences between treatments. The entire werea of the Yeh Ho watershed has a uniform C-Organic concentration, so that the difference in rice yield was not caused by C-Organic soil / soil fertility. The concentration of soil C-Organic / soil fertility for all future locations still seems to be improved, namely by paying attention to rice straw, which was one of the cheap and easily available $\mathrm{K}$ sources in paddy fields. Every 5 tons of straw contains $\mathrm{K}$ equivalent to $50 \mathrm{~kg} \mathrm{KCl}$. About $80 \%$ of $\mathrm{K}$ absorbed by rice plants was in straw. Therefore, returning straw to paddy fields can partially meet the $\mathrm{K}$ nutrients needed by plants. Most rice fields in Bali have very low levels of organic matter (C-Organic $<2 \%$ ). Thwas condition was partly due to farmers not returning straw to the soil, planting rice continuously, transporting all the crops out, and using inorganic fertilizers without organic fertilizer. The level of organic matter greatly affects the productivity of lowland rice; the lower the level of organic matter, the lower the productivity of the land. Poor soil organic matter will reduce its reswastance to fertilizers so that the efficiency of inorganic fertilizers decreases because most of the fertilizer was lost.

The physics function of straw was: 1) improving soil structure because it can bind soil particles to a steady aggregate, 2) improve soil pore size dwastribution so that the water holding capacity of the soil increases and the air movement (aeration) in the soil becomes more good, and 3) reduce soil temperature fluctuations. The important chemical functions of organic matter were: 1) although it contains little nutrients, organic fertilizer can provide macro nutrients 2) increase the cation exchange capacity (CEC) of the soil, and 3) form complex compounds with metal ions so that the metals not powason the plants.

The biological function of straw was a food source for soil microbes. With sufficient organic material available, the activity of soil organwasms can improve nutrient availability, nutrient cycles, and the formation of micro and macro pores in the soil. In general, the recommendation of $\mathrm{KCl}$ fertilizer for lowland $\mathrm{K}$ land was $100 \mathrm{~kg} \mathrm{KCl} / \mathrm{ha}$, and for moderate $\mathrm{K}$ to $50 \mathrm{~kg} \mathrm{KCl} / \mathrm{ha}$. Giving $5 \mathrm{t} / \mathrm{ha}$ straw can substrate nutrients equivalent to $50 \mathrm{~kg} \mathrm{KCl}$ and $20 \mathrm{~kg}$ urea/ha.

Considering the importance of organic matter for soil fertility, nutrient management must be carried out in an integrated manner by providing inorganic fertilizers and organic materials or organic fertilizers, among others straw. The scarcity of fertilizers which has lasted several seasons in several regions wasfewered to reduce national rice production. efforts need to be made to utilize organic material in the local location (in situ) such as straw. Thwas rice harvest can supply a portion of $\mathrm{K}$ nutrient requirements thereby reducing the dose of $\mathrm{KCl}$ fertilizer.

The concentration of $\mathrm{K}$ in water when the plant age 55 DAPappeared to be significantly different in the upstream werea on the land planted with Mekongga varieties, it appewered that once every 8 days irrigation had the highest concentration of $\mathrm{K}$, although it was not significantly different from irrigation 4 days. The concentration of $\mathrm{K}$ water on the land planted with Inpari 1 irrigation 4 days and irrigation 8 days was not significantly different and Inpari 10 Laeya. It was significantly different after continuous irrigation, irrigation 4 days and irrigation every 8 days (Table 3 ).

Table3. Effect of watershed location, irrigation technique, and varieties on the concentration of water $K$ on plants aged 55 days after planting

\begin{tabular}{|c|c|c|c|c|c|}
\hline \multirow{3}{*}{$\begin{array}{c}\text { Watershed } \\
\text { Location }\end{array}$} & \multirow{2}{*}{$\begin{array}{c}\text { Irrigation } \\
\text { Technique }\end{array}$} & \multicolumn{4}{|c|}{ Concentration of water K(\%) } \\
\cline { 3 - 5 } & & \multicolumn{3}{|c|}{ Varieties } \\
\cline { 3 - 5 } & & Mekongga & Inpari 1 & Inpari 10 Laeya & \\
\hline Upstream & Continuous & $0.50^{\mathrm{g}}$ & $1.30^{\mathrm{b}-\mathrm{g}}$ & $1.24^{\mathrm{c}-\mathrm{g}}$ & 1.01 \\
\hline & Every 4 days & $0.94^{\mathrm{fg}}$ & $1.01^{\mathrm{e}-\mathrm{g}}$ & $0.81^{\mathrm{f} g}$ & 0.92 \\
\hline & Every 8 days & $0.87^{\mathrm{fg}}$ & $1.01^{\mathrm{e}-\mathrm{g}}$ & $1.05^{\mathrm{d}-\mathrm{g}}$ & 0.98 \\
\hline & Average & $\mathbf{0 . 7 7}$ & $\mathbf{1 . 1 1}$ & $\mathbf{1 . 0 3}$ & $\mathbf{0 . 9 7}$ \\
\hline
\end{tabular}


Intermitten Irrigation on Rice Varieties in Watersheds

\begin{tabular}{|c|c|c|c|c|c|}
\hline Middle & Continuous & $1.06^{\mathrm{d}-\mathrm{g}}$ & $2.72^{\mathrm{a}-\mathrm{c}}$ & $2.58^{\mathrm{a}-\mathrm{e}}$ & 2.12 \\
\hline & Every 4 days & $2.60^{\mathrm{a}-\mathrm{d}}$ & $2.19^{\mathrm{a}-\mathrm{f}}$ & $1.87^{\mathrm{a}-\mathrm{g}}$ & 2.22 \\
\hline & Every 8 days & $2.82^{\mathrm{ab}}$ & $3.00^{\mathrm{a}}$ & $2.96^{\mathrm{a}}$ & 2.93 \\
\hline & Average & $\mathbf{2 . 1 6}$ & $\mathbf{2 . 6 4}$ & $\mathbf{2 . 4 7}$ & $\mathbf{2 . 4 2}$ \\
\hline & Continuous & $2.04^{\mathrm{a}-\mathrm{g}}$ & $3.18^{\mathrm{a}}$ & $1.00^{\mathrm{e}-\mathrm{g}}$ & 2.07 \\
\hline & Every 4 days & $1.05^{\mathrm{d}-\mathrm{g}}$ & $1.09^{\mathrm{c}-\mathrm{g}}$ & $0.80^{\mathrm{fg}}$ & 0.98 \\
\hline & Every8 days & $0.99^{\mathrm{fg}}$ & $0.98^{\mathrm{fg}}$ & $0.79^{\mathrm{fg}}$ & 0.92 \\
\hline & Average & $\mathbf{1 . 3 6}$ & $\mathbf{1 . 7 5}$ & $\mathbf{0 . 8 6}$ & $\mathbf{1 . 3 2}$ \\
\hline
\end{tabular}

Note: Numbers in the same column and row followed by the same lettersignificantly different based on 5\% $D M R T$

The concentration of $\mathrm{K}$ in water appears to be significantly different in the upstream werea on land planted with Mekongga varieties. It appears that once every 8 days irrigation has the highest $\mathrm{K}$ concentration with irrigation once every 4 days. The concentration of $\mathrm{K}$ water on the land planted with Inpari 10 Laeyaappewered to be significantly different after being given continuous irrigation, irrigation 4 days and irrigation every 8 days.

\subsection{Yield Components and Grain Yield}

In the upstream, middle and downstream watershed locations the highest number of panicles / clumps occurred in the Inpari 10 Laeya variety and was significantly different from the Mekongga variety and Inpari 1 variety by irrigation every 8 days. Watering every 8 days resulted in the highest number of panicles / clumps in LaeyaInpari 10 rice varieties (Table 4).

Table4. Effect of watershedlocation, irrigation technique, and varieties on the number of panicles/clump

\begin{tabular}{|c|c|c|c|c|c|}
\hline \multirow{3}{*}{$\begin{array}{l}\text { Watershed } \\
\text { Location }\end{array}$} & \multirow{3}{*}{$\begin{array}{l}\text { Irrigation } \\
\text { Technique }\end{array}$} & \multicolumn{3}{|c|}{ Number of panicles/clump } & (panicles) \\
\hline & & \multicolumn{3}{|c|}{ Varieties } & \multirow{2}{*}{ Average } \\
\hline & & Mekongga & Inpari 1 & Inpari 10 Laeya & \\
\hline \multirow{4}{*}{ Upstream } & Continuous & $13.79^{\mathrm{f}}$ & $12.66^{\mathrm{f}}$ & $12.39^{\mathrm{f}}$ & 12.94 \\
\hline & Every 4 days & $12.04^{\mathrm{f}}$ & $15.64^{\mathrm{d}-\mathrm{f}}$ & $15.28^{\mathrm{d}-\mathrm{f}}$ & 14.32 \\
\hline & Every 8 days & $18.71^{\mathrm{bc}}$ & $22.07^{\mathrm{a}-\mathrm{c}}$ & $22.44^{\mathrm{a}-\mathrm{b}}$ & 21.07 \\
\hline & Average & 14.85 & 16.79 & 16.70 & 16.11 \\
\hline \multirow[t]{4}{*}{ Middle } & Continuous & $15.43^{\mathrm{d}-\mathrm{f}}$ & $13.67^{\mathrm{f}}$ & $14.23^{\mathrm{e}-\mathrm{f}}$ & 14.44 \\
\hline & Every 4 days & $13.58^{\mathrm{f}}$ & $13.72^{f}$ & $18.20^{\mathrm{c}-\mathrm{e}}$ & 15.17 \\
\hline & Every 8 days & $15.52^{\mathrm{d}-\mathrm{f}}$ & $22.96^{\mathrm{ab}}$ & $23.10^{a}$ & 20.53 \\
\hline & Average & 14.84 & 16.78 & 18.51 & 16.71 \\
\hline \multirow[t]{4}{*}{ Downstream } & Continuous & $13.06^{\mathrm{f}}$ & $14.27^{\mathrm{e}-\mathrm{f}}$ & $13.68^{\mathrm{f}}$ & 13.67 \\
\hline & Every 4 days & $14.50^{\mathrm{def}}$ & $12.12^{\mathrm{f}}$ & $13.11^{\mathrm{f}}$ & 13.24 \\
\hline & Every8 days & $21.97^{\mathrm{abc}}$ & $23.70^{\mathrm{a}}$ & $24.20^{a}$ & 23.29 \\
\hline & Average & 16.51 & 16.70 & 17.00 & 16.73 \\
\hline
\end{tabular}

Note: Numbers in the same column and row followed by the same letter significantly different based on 5\% DMRT

The highest yield component of 1000 grains occurs in Inpari 10 Laeyavariety for upstream, middle and downstream whereas with irrigation every 8 days and appears to be significantly different from Mekongga and Inpari 1 varieties (Table 5).

Table5. Effect of watershedlocation, irrigation technique, and varieties on the weight of 1000 grains

\begin{tabular}{|c|c|c|c|c|c|}
\hline \multirow{3}{*}{$\begin{array}{l}\text { Watershed } \\
\text { Location }\end{array}$} & \multirow{3}{*}{$\begin{array}{l}\text { Irrigation } \\
\text { Technique }\end{array}$} & \multicolumn{4}{|c|}{ Weight of 1000 grains (g) } \\
\hline & & \multicolumn{3}{|c|}{ Varieties } & \multirow{2}{*}{ Average } \\
\hline & & Mekongga & Inpari 1 & Inpari 10 Laeya & \\
\hline \multirow[t]{4}{*}{ Upstream } & Continuous & $28.23^{\mathrm{f}-\mathrm{j}}$ & $28.73^{\mathrm{d}-j}$ & $30.78^{\mathrm{b}-\mathrm{e}}$ & 29.25 \\
\hline & Every 4 days & $28.14^{\mathrm{f}-\mathrm{j}}$ & $27.96^{\mathrm{g}-\mathrm{k}}$ & $30.01^{\mathrm{b}-\mathrm{g}}$ & 28.70 \\
\hline & Every 8 days & $28.57^{\mathrm{e}-\mathrm{j}}$ & $29.18^{\mathrm{c}-\mathrm{i}}$ & $32.36^{\mathrm{a}-\mathrm{b}}$ & 30.03 \\
\hline & Average & 28.31 & 28.62 & 31.05 & 29.33 \\
\hline \multirow[t]{4}{*}{ Middle } & Continuous & $28.00^{\mathrm{g}-\mathrm{k}}$ & $28.56^{\mathrm{e}-\mathrm{j}}$ & $31.22^{\mathrm{a}-\mathrm{c}}$ & 29.26 \\
\hline & Every 4 days & $27.56^{\mathrm{h}-\mathrm{k}}$ & $29.78^{\mathrm{c}-\mathrm{h}}$ & $32.44^{\mathrm{a}-\mathrm{b}}$ & 29.93 \\
\hline & Every 8 days & $27.33^{i-k}$ & $28.00^{\mathrm{g}-\mathrm{k}}$ & $33.11^{\mathrm{a}}$ & 29.48 \\
\hline & Average & 27.63 & 28.78 & 32.26 & 29.56 \\
\hline
\end{tabular}




\begin{tabular}{|c|c|c|c|c|c|}
\hline Downstream & Continuous & $26.56^{\mathrm{jk}}$ & $28.79^{\mathrm{d}-\mathrm{j}}$ & $28.72^{\mathrm{d}-\mathrm{j}}$ & 28.02 \\
\hline & Every 4 days & $26.03^{\mathrm{k}}$ & $29.07^{\mathrm{c}-\mathrm{i}}$ & $30.33^{\mathrm{b}-\mathrm{f}}$ & 28.48 \\
\hline & Every8 days & $28.44^{\mathrm{f}-\mathrm{j}}$ & $27.56^{\mathrm{h}-\mathrm{k}}$ & $30.90^{\mathrm{a}-\mathrm{c}}$ & 28.97 \\
\hline & Average & $\mathbf{2 7 . 0 1}$ & $\mathbf{2 8 . 4 7}$ & $\mathbf{2 9 . 9 9}$ & $\mathbf{2 8 . 4 9}$ \\
\hline
\end{tabular}

Note: Numbers in the same column and row followed by the same lettersignificantly different based on 5\% DMRT

Table 6 shows the interaction of location, irrigation and varieties that rice production in upstream and middle wereaswas lower than downstream. In the upstream werea of Inpari 1 rice the yield was significantly different from Mekongga and Inpari 10 Laeya if given continuous irrigation and irrigation 4 days. Rice Inpari 10 The highest yield was compared with Inpari 1 and Mekongga. In the middle watershed area, Inparil yield was lower and significantly different than the Mekongga variety rice and Inpari 10 Laeya variety with continuous irrigation, irrigation 4 days and irrigation every 8 days. In the downstream werea of Inpari 10 varieties, the yield was higher than Mekongga rice and Inpari 1 with continuous irrigation, irrigation 4 days and irrigation every 8 days. Watering once every 8 days on LaeyaInpari 10 rice was able to produce the highest milled unhulled rice (GKG) which was $8.04 \mathrm{t} / \mathrm{ha}$. For further development of the Inpari 10 Laeya variety with a package of irrigation technology once every 8 days can be developed thoroughly in the Yeh Ho watershed werea as a rice production technology that was more efficient using water without reducing rice production.

Table6. Effect of watershedlocation, irrigation technique, and varieties on milled dry grain yield

\begin{tabular}{|c|c|c|c|c|c|}
\hline \multirow{3}{*}{$\begin{array}{l}\text { Watershed } \\
\text { Location }\end{array}$} & \multirow{3}{*}{$\begin{array}{l}\text { Irrigation } \\
\text { Technique }\end{array}$} & \multicolumn{4}{|c|}{ Milled dry grain yield ( t/ha) } \\
\hline & & \multicolumn{3}{|c|}{ Varieties } & \multirow{2}{*}{ Average } \\
\hline & & Mekongga & Inpari 1 & Inpari 10 Laeya & \\
\hline \multirow[t]{4}{*}{ Upstream } & Continuous & $6.24^{\mathrm{d}-\mathrm{h}}$ & $5.31^{\mathrm{g}-\mathrm{h}}$ & $6.26^{\mathrm{d}-\mathrm{h}}$ & 5.93 \\
\hline & Every 4 days & $6.41^{\mathrm{c}-\mathrm{g}}$ & $5.40^{\mathrm{f}-\mathrm{h}}$ & $6.69^{c-e}$ & 6.17 \\
\hline & Every 8 days & $6.93^{\mathrm{b}-\mathrm{e}}$ & $7.29^{\mathrm{a}-\mathrm{d}}$ & $7.59^{\mathrm{a}-\mathrm{c}}$ & 7.27 \\
\hline & Average & 6.53 & 6.00 & 6.84 & 6.46 \\
\hline \multirow[t]{4}{*}{ Middle } & Continuous & $6.33^{\mathrm{d}-\mathrm{h}}$ & $5.21^{\mathrm{h}}$ & $6.62^{c-e}$ & 6.06 \\
\hline & Every 4 days & $6.21^{\mathrm{d}-\mathrm{h}}$ & $5.96^{\mathrm{e}-\mathrm{h}}$ & $6.66^{c-e}$ & 6.27 \\
\hline & Every 8 days & $6.99^{\mathrm{a}-\mathrm{e}}$ & $6.47^{\mathrm{c}-\mathrm{f}}$ & $7.59^{\mathrm{a}-\mathrm{c}}$ & 7.02 \\
\hline & Average & 6.51 & 5.88 & 6.96 & 6.45 \\
\hline \multirow[t]{4}{*}{ Downstream } & Continuous & $6.66^{\mathrm{c}-\mathrm{e}}$ & $6.93^{\mathrm{b}-\mathrm{e}}$ & $6.95^{\mathrm{a}-\mathrm{e}}$ & 6.85 \\
\hline & Every 4 days & $6.91^{\mathrm{b}-\mathrm{e}}$ & $6.89^{\mathrm{b}-\mathrm{e}}$ & $7.25^{\mathrm{a}-\mathrm{d}}$ & 7.02 \\
\hline & Every 8 days & $8.04^{\mathrm{a}-\mathrm{b}}$ & $7.59^{\mathrm{a}-\mathrm{c}}$ & $8.14^{\mathrm{a}}$ & 7.92 \\
\hline & Average & 7.20 & 7.14 & 7.44 & 7.26 \\
\hline
\end{tabular}

Note: Numbers in the same column and row followed by the same lettersignificantly different based on 5\% DMRT

Interaction of watershed location, irrigation techniqueand varieties of MPD occur, rice production in upstream and middle was lower than downstream. In the upstream of Inpari 1 rice, the yield was significantly different from Mekongga and Inpari 10 Laeya when given continuous irrigation and irrigation 4 days. Rice Inpari 10 The highest yield was compwered with Inpari 1 and Mekongga after being given irrigation every 8 days. In the middle werea of Inpari 1 rice the yield was lower and significantly different from Mekongga rice and Inpari 10 Laeya with continuous irrigation, irrigation 4 days and irrigation every 8 days. In the downstream werea once every 8 days irrigation carried out on LaeyaInpari 10 rice produces the highest milled dry grain, which was $8.14 \mathrm{t} / \mathrm{ha}$.

The highest overall yield of panicles / clumps of rice was Inpari 10 Laeya and significantly different from Mekongga rice and Inpari 1 rice by irrigation every 8 days. Vwasually the irrigation of 8 days showed that rice growth was healthier and resulted in a higher number of panicles / clumps in LaeyaInpari 10 rice varieties. The highest 1000 grain weight in Inpari 10 Laeya varieties with irrigation every 8 days and appears to be significantly different from Mekongga and Inpari rice varieties 1 . Intermittent irrigation every 8 days can reduce water use and keep mowasturemowast during the vegetative stage, to allow more oxygen for root growth. Based on the results of thwas study, it can increase rice yield $15.13 \%$.

\section{CONCLUSiON}

Irrigation every 8 days produces the weight of dry unhulled grain, while the lowest weight of dry grain was produced from continuous irrigation. The new superior rice varieties Inpari 10 Laeya 
produce the highest weight of dry milled rice. The location of the upstream watershed produces the highest dry milled grain weight, while the lowest in the middle watershed location.

\section{ACKNOWLEDGMENT}

Infinite thanks say the author conveyed to: Prof. Dr. DjokoPrajitno, Dr. Abdul Syukur, and Dr. HeruHendrayana, as promoters who has contributed valuable thoughts, advice, encouragement, criticism and suggestions. The DG of theIndonesian Agency for Research and Development (IAARD) on my doctorl scholarships at the GadjahMada University Yogyakarta. The director of the IndonesianCenter for Assessment Institute of Agricultural Technology, and the Head of Bali Assessment Institute of Agricultural Technology who have given the opportunity for me to continue my doctoral study.

\section{REFERENCES}

[1] Arsana, I.G.K.D., S.Yahya, A.P. Lontoh\& H. Pane 2003. Hubungan antara penggenangan dini dan potensire doks, Produksi etil end an pengaruhnya terhadap pertumbuhandan hasil padi(Oryzasativa) swastem Tabela. BuletinAgronomi Vol. 31 No. 2.

[2] Arsana, I.G.K.D. 2006.Peranan varietas unggul baru padi dalam mendukung usahatani tanaman-ternak di SubakDelodBakas, Klungkung, Bali. Didalam : (eds.). Suprihatno, B., (eds.). Inovasi teknologi padi. Menuju swasembada beras berkelanjutan. Buku Dua Pusat Penelitiandan PengembanganTanaman Pangan. Hal : 477-488.

[3] Asdak, C. 2007. Hidrologidanpengelolaandaerahaliransungai. GajahMada University Press. Yogyakarta.

[4] Bouman, B. A. M., R. M Lampayan \& T.P Toung. 2007. Water management in irrigated rice : Coping with water Scarcity. International Rice ResearchInstitude. Los Banos. Philippines. 50 p.

[5] Chiu, W.T.F., Z. S. Chen, W.C. Cosico\& F.B. Aglibut. 2000. Management of Slope Lands in Asia-Pacific Region. Food \& Fertilizer Technology Center for the Asian and PasificRegion. Taipei, Taiwan, ROC.90 p.

[6] Engelman, R. \& P. Le Roy. 1993. Sustaining Water Population and the Future of Renewable Water Supplies. Population Action International. Washington. DC.

[7] Fagi, A.M. C.P. Mamaril \& M.Syam 2009 RevolusiHijau. Perandan Dinamika Lembaga Rwaset. Balai Besar Penelitian Tanaman Padi 34 hal.

[8] Fagi, A.M., I.Las\& M Syam. 2002. Penelittian Padi Menjawab Tantangan Ketahanan Pangan Nasional. Balai Penelitian Tanaman Padi, Bada Litbang Pertanian, 29 hal.

[9] Fagi, A.M. 2007. Menyiasati Pengelolaan Sumber Daya Air untuk Pertanian Masa Depan. Iptek Tanaman Pangan, Vol. 2, 1-11.

[10] FAO [Food and Agriculture Organization], 1996.Food Balance sheet. FAOStatwastical Series 131, Rome.

[11] Huke, R. 1976. Geography and Climate of Rice. Didalam Climate and Rice. IRRI, Los Banos, Laguna, Philippines, pp. 31-50.

[12] Noordwijk, N.P. FahmuddinAgus, DidikSuprayogo, KurniatunHairiah, GamalPasya, Bruno verbwastdan Farida. 2004. PerananAgroforestrodalam Daerah Aliran Sungai (DAS). Agrivita, JurnalTentangllmuilmuPertanian. 139 hal.

[13] Pawitan,H. \& Murdiyarso,D.1993. Tinjauan Hidrologi Toposequensdalam Meningkatkan Efwasiensi Pemakaian Air Pertanian. Proseding Seminar Pengelolaan Tata Air dan Pemanfaatannyadalam SatuKesatuan Toposequens. Kerjasama PERHIMPI danBadanLitbangDeptan 1993.Cilacap, 7-8 Oktober 1993.Hal.41-50.

[14] Sharma, P.S., G. Pantuwan, K.T Ingram \& S.K De Datta. 1994. Rainfed Lowland rice roots : soil and hydrological effects. Di dalam: Kirk G.J.D (eds). Rice roots : nutrient and water use. Selected papers from the international rice research conference. International Rice Research Institute. Los Banos. Laguna. Philippines. p: 55-66.

[15] Subagyono, K. \& E. Sumarini. 2007. Adaptasi Pertanian Terhadap PerubahanIklim. Seminar Bulanan Bada Meteorologidan Geofwasika (BMG). IPB, Dramaga, Bogor, 28 Juni 2007.

Citation: I G.K.Dana Arsanal, Made J.Mejaya, "Intermitten Irrigation on Rice Varieties in Watersheds" International Journal of Research Studies in Agricultural Sciences (IJRSAS), 2019; 5(10), pp. 1-8, http://dx.doi.org/10.20431/2454-6224.0510001

Copyright: () 2019 Authors. This is an open-access article distributed under the terms of the Creative Commons Attribution License, which permits unrestricted use, distribution, and reproduction in any medium, provided the original author and source are credited. 